\title{
Orality, gender and sacred texts in the context of tele-evangelism
}

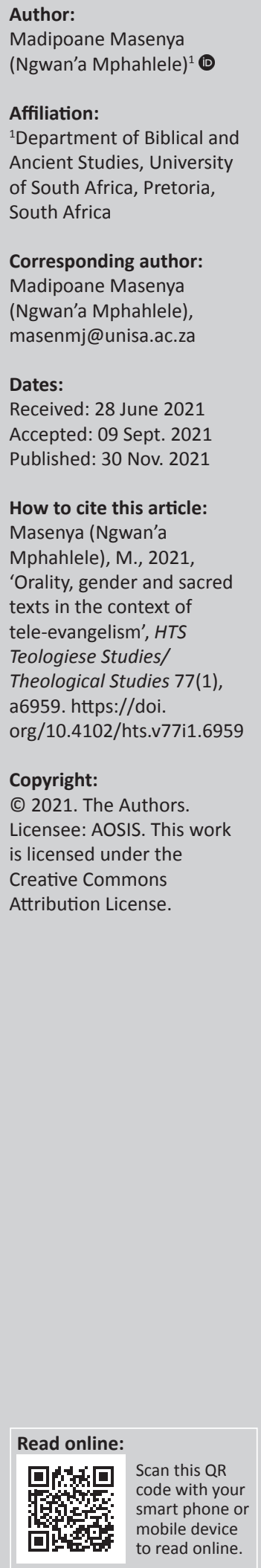

In oral cultures such as (traditional) African cultures and the cultures that eventually produced the Christian Bible, women formed an integral part of the art of storytelling. In patriarchal cultures where the normativity of a male is taken for granted, once orality was tampered with by that which happens in the sphere traditionally reserved for men as in, for example, the introduction of literacy, the important role of women as storytellers, including the telling of the stories of Jesus of Nazareth (read: biblical discourse) gets tampered with by subordination and silencing amongst others. Whilst the participation of women in ordained ministry and the delivery of public biblical discourse still remains a challenge in many African ecclesiastical settings, the advent of the digital era (cf. tele-evangelism in this essay) is not necessarily helpful towards the affirmation of women, especially first ladies in the context of huge ministries and mega churches.

Contribution: The present essay seeks to answer the following main question: If the intersection among orality, gender, sacred texts and biblical discourse are analysed in the context of the full participation of African Christian women, especially the wives of the 'men of God', which power dynamics regarding gender and biblical discourse can be unravelled?

Keywords: biblical discourse/sermon; orality; gender; digital era tele-evangelists; African women; first ladies in context of ministry; charismatic and neo-Pentecostal churches.

\section{Introduction}

In the digital age, personal computers and other subsequent technologies are introduced in order to enable the transfer of information with ease and speed. A shift has thus occurred from an industrial-based to an information-based economy with the computer and other technology devices as media or conduits for communication. In this context that sets great store by digitalisation, I would like to foreground the role of television as a conduit through which patriarchy remains entrenched. The word 'discourse' as used in this essay will mean written or spoken communication. Reference to biblical discourse will entail a written and spoken communication, which derives from the Bible. A discourse is an extended verbal expression in speech or writing. In the present essay, religious discourse will basically refer to a sermon (especially in the context of tele-evangelism) by the owners of large ministries especially in the context of the neo-Pentecostal and charismatic churches.

As already observed, it is in this information-based economy context that I would like to explore the role of television as a medium through which the dynamics of orality, power, gender in the delivery of religious discourse play out.

The underlying assumption of the main argument of this essay is thus as follows: there is an intersection among power, gender, orality and public discourse in general and biblical discourse in particular. The preceding interface, it is argued, was already manifest in the history of the formation of the biblical canon, whether the canon of the Hebrew Bible or the canon of the New Testament/Second Testament (Culley 1963; Niditch 1996). The observation by Joana Dewey with regard to the latter is worth noting. With the introduction of the written authoritative tradition though, the role of women became minimal and marginalised compared with the scenario of the earlier oral tradition. At the same time, their oral stories' content, 'would be determined less and less by their own memories and handing on of traditions and more and more by what circulated back into the telling from the manuscripts' (Dewey 1998:23). So once the publics featured (cf. the phenomenon of literacy as it is was made manifest in the canonisation of the texts), an exercise that was performed mainly if not solely by men of stature or elitist men, the female voice, became largely excluded and even muted in that non-digital context. In the preceding scenario, the power

Note: Special Collection: Reception of Biblical Discourse in Africa, sub-edited by Itumeleng Mothoagae (University of South Africa). 
dynamics at display are visibilised in the intersection between male gender and socio-economic class.

The intersection of power, gender, orality and biblical public discourse is also notable even in our present-day contexts.

Female subordination, it may be argued, is not enhanced by the level of the technological advancement in a specific context; on the contrary, it may be argued that the digital space has come to expose not only the existing economic disparities between persons and countries but also between genders even in the context of the delivery of biblical discourse. The case in point to be provided is that of the power of heterosexually married men, especially the founders of mega-churches. Their wives seldom or never get to share in tele-evangelism and so Bowler (2021) argues about the wives of these powerful men of God:

In almost every spiritual empire, there is a 'she' ... Yet despite their influence and wealth, these women are, in the main, denied the most important symbol of spiritual power - the pulpit. (n.p.)

Whilst the equality between genders may be mouthed especially by those whose power has been legitimated by patriarchy, in real life, women, including those attached as wives to powerful men like tele-evangelists and founders of huge ministries, remain invisible in the discharge of biblical discourse. I thus agree with Sarojini Nadar, especially within the Pentecostal church tradition, that whilst equality between the sexes can be proclaimed, in real life, the opposite holds. From Nadar's interaction with a moderator from one of the Pentecostal churches here in South Africa, she was informed that women can participate fully in the Church, including even proceeding to the ordination level if they so wished. Nadar (2005) is not persuaded though as she observes:

However the reality is that they do not. They are still relegated to what has been considered traditional tasks for women (e.g. making the tea, being in charge of the Sunday school, helping with the 'sisters' meetings', etc.) and they very rarely take up leadership positions. (pp. 64-65)

As it will be argued later in this essay, the wives of the powerful tele-evangelists, irrespective of their race and geopolitical location on the globe, may be mentioned on television as pastors' wives or even pastors; however, the women seldom feature in the same digital space as equal partners in the dispatch of biblical discourse (read: sermons and/or Bible studies). The words of Ruether (1993) come to mind here:

Women are categorized as less capable than men of moral selfcontrol and reason. They can play only a passive role in the giving and receiving of ministry. They should keep silent. (p. 195)

It is pertinent that the subject of orality be featured in the discussion of biblical discourse in the digital era. Why so? The key story tellers in varied African contexts were basically females.
It may be safe to conclude that depending on their educational background and age amongst others, some African Christian women will prefer to access orally delivered sermons, in a contact setting and preferably, in their own mother tongue. The following scenario comes to mind here. A few years back, whilst in a minibus en route to a conference, one elderly woman requested that a prayer be made against the use of English as a medium of communication during the conference sessions!

Most of the women were birthed and nurtured in oral African contexts. It is in such contexts that the oral nature of African contexts formed part of our nurture and formation as evident in the following examples: In a grinding space, women would sing fitting songs. Similarly, restless babies strapped to the backs of their mothers would be lulled by the melodies of specific songs. As young girls, an achievement in household chores such as having successfully brought a bundle of (fire) wood home would be celebrated with the singing of our praise names by our mothers and/or grandmothers as in the following:

Ke Moremadi'a Morwakom'a Phaahla (le Tlou wa Monareng),

Phaahla Hlabana ya mahlo'a maso, Makatakapitsi ...,

Ke Ngwana'kgoši'a, Matime'a letšatši, Raborufi,

Ntsho ke hlaba dithamaga, ditšhweu ke šia mebala,

Tsetsebekw'a thab'a tlapa la gabo mosadi'a batho.

Ke motho wa boseya nokeng ka legapa, ka nkgo ke šia go imelwa,

Ka pitša ke tšhaba mešidi,

Ke motho'abo Photophoto'a Kwen'a bodiba,

Motho'abo -pula ye e sa dumego, re bona ka marothodi ....

It is a fact that even in today's technological advanced contexts, African women both in South Africa and dare one say, in the rest of sub-Saharan Africa, continue not only to form the vast majority of people who sit in our church pews. African Christian women also, in their own way, interact with sermons, whether as recipients mostly from male clergy persons who continue to be the legitimate interpreters in mostly female ecclesiastical settings, or from their own circles as women clergy persons and even more importantly for the present essay, as wives of clergy persons and founders of huge ministries.

As already observed in the previous paragraphs, what is worthy of note though, is that in patriarchal contexts, be it in the contexts of the early history of the formation or transmission of biblical texts as canon or today, once the public space intrudes, female voices become basically muted. In order to demonstrate the preceding observation, the discussion will first be situated within the early Mediterranean context. In the latter setting, both women (and men) were storytellers of the good news about Jesus the Christ. I will then give an example of how, despite their basic absence in tele-evangelism, some women create own grassroots biblical discourse informed by their own unique experiences. In 
order to buttress the notion of the intersection between power, orality, gender and biblical discourse in the digital era, I will then comment on the invisibility of pastors' / teleevangelists' wives in tele-evangelism.

Joanna Dewey provides us with a window into the theme of the intersection among orality, power and gender in the context of the formation of the canon of the New Testament. We now turn our attention to the preceding theme in the paragraphs that follow:

\section{The intersection between orality, power and gender and the written word in the herstory/history of early Christian origins}

Recent feminist scholarship on the herstory/history of early Christian origins has convincingly argued for the existence of an alternative tradition in the Jesus movement and early Christianity. Such a tradition could have suggested a very different construction of Christian theology and so argues Ruether (1993):

\begin{abstract}
([A] tradition that featured) women as equal with men in the divine mandate of creation; restored to this equality in Christ; the gifts of the Spirit poured out on men and women alike; the Church in the Messianic society, not over against creation but over against the systems of domination. We see hints of this vision in the New Testament. But the Deutero-Pauline recasting of Christianity in patriarchal terms made this inclusive theology nonnormative. (pp. 195-196; author's own brackets and emphasis)
\end{abstract}

Although the preceding quote from Radfort Ruether on the androcentric recasting of Christianity is mentioned in the context of Deutero-Pauline texts, a recasting that made inclusive theology to be against the norm, it will not be an exaggeration to argue (even as we will note from Dewey's insights here) that the New Testament canon as such, basically endorses an exclusive theology, one that basically excludes the female voices, voices that had albeit also formed part of the earlier storytelling practice of the life and ministry of Jesus of Nazareth.

In her monumental work on the reconstruction of women in the history of early Christian orgins, Schüssler Fiorenza buttresses the preceding observation when she cautions that we should be weary of reading the New Testament writings as objective factual reports of early Christian history and development. She continues:

The rarity of women's mention in the sources would thus adequately reflect the actual history of their activity in the early church. Such a presupposition however, neglects the methodological insights of criticism, source criticism and redaction criticism, which have pointed out that the early writings, are not at all objective, factual transcripts but pastorally engaged writings. (Schüssler Fiorenza 1994:49)

Unlike in today's highly technological context, of course also depending on one's geopolitical location on the globe, technically speaking, argues Joana Dewey, the ancient media world was a manuscript culture with high residual orality. The phrase, 'residual orality', is used to depict a culture from the perspective of the literate elite who used writing as a matter of fact, to rule the empire. Dewey reminds us that in that predominantly oral Mediterranean context for the rest of the population (i.e. apart from the literate elite, who were mostly men in that patriarchal setting) neither publications existed nor was there any need for writing. The need for writing if it did exist was insignificant. The existing culture therefore, did not support the spread of literacy. Unlike in present-day 21st century global and digital contexts, for most people then (cf. also in traditional African settings), literacy was neither an economic nor a social handicap because life was basically conducted orally (Dewey 1998:21). Like all the other members of the communities then, Christians also engaged in storytelling. Stories would be told by individuals to others. Dewey observes: 'Early Christian women were proclaimers and storytellers and receptive listeners' (Dewey 1998:22).

However, noteworthy is the fact that the Roman Empire used not only its armies but also its power over the written word to create the most totalitarian empire the West had known until that time. Christian writings only came to be appealed to as authoritative in the mid-second century CE. If Christianity remained orally based, women possessed their own oral traditions, which were told amongst other women whilst they also made an important contribution to the common tradition familiar to both women and men. The preceding setting reminds one of the introduction of the monarchy in ancient Israel. The introduction of the monarchy and its literacy in ancient Israel did not weaken the power of the oral tradition that existed then. So was the case even in first century Mediterranean world. And so Dewey (1998:23) asserts, 'oral tradition did not end as Christian authority became increasingly manuscript-based. Women continued to tell and hear stories, for they and most men remained nonliterate into the modern period'.

So in that non-digital era, the power of orality as manifested in the circulation of the stories by both women and men continued to be felt even despite the reality that the authority of Christian texts became intertwined with literacy in the form of the manuscripts. It is worth noting that the written tradition, mostly by men in the public sphere came to control the oral tradition in which women also participated.

However, with the written authoritative tradition becoming more and more entrenched and fixed (as canon), the role of women became minimal and marginalised, compared with the earlier egalitarian oral tradition whilst their oral stories' content, 'would be determined less and less by their own memories and handing on of traditions and more and more by what circulated back into the telling from the manuscripts'. Hence, the observation made earlier on in this essay, which is, once the public (male) space features, in this case, in the form of (or as it was visibilised by) a practice such as writing and literacy, a space that has traditionally been linked with men in patriarchal contexts, the power and impact of women, even in the dispatch of religious discourse, receded. 
Dewey (1998) can thus rightly point out that:

[T] he written tradition controls the content of the continuing oral tradition... But the move to manuscript authority and literate power was important in its own right and has continued to have an impact on generations into the present (including the African contexts)... it is for this reason the written texts of the New Testament still form our imaginations about Jesus, the early church and early Christian women. (p. 23; author's own brackets)

The New Testament is thus not a value-neutral survey of Christianity. It is tilted towards those of higher social location, basically educated literate men who held to a patriarchal ideal including that of the subordination of women (Dewey 1998:27). However, as observed by Ruether in the introduction to the present section, there are glimpses from the text of the New Testament itself of the participation of women (and men) in the public ministry of the word. It could thus be argued that women, just like men, then already participated in what could in the context of the present theme, be called biblical discourse.

Elisabeth Schüssler Fiorenza's (1994) observation on this participation of women in public ministry is noteworthy:

The Pauline literature and Acts still allow us to recognize that women were among the most prominent missionaries and leaders in the early Christian movement. They were apostles and ministers like Paul, and some were his co-workers. They were teachers, preachers, and competitors in the race of the gospel. They founded house churches and, as prominent patrons, used their influence for the missionaries and Christians. If we compare their leadership with the ministry of the later deaconesses, it is striking that their authority and ministry were neither restricted to women and children, nor exercised only in specific feminine roles and functions. ${ }^{1}$

It is clear that early Christian women in that non-digital context were engaged in biblical discourse as 'They were teachers, preachers and competitors in the race of the gospel. They founded house churches and, as prominent patrons, used their influence for the missionaries and Christians' (Schüssler Fiorenza 1994:183-184).

The preceding discussion leads us to investigate the impact of the authority of the text especially on African women: a text that like many other African sacred texts emerged from oral contexts but ended up as a written canonical text. This text emerged from the efforts of both women and men whilst telling of the stories of Jesus of Nazareth but ended up being canonised by men. What will be important in the next section, is how African Christian women in non-digital, but Yesuconfessing Christian contexts, construct their own biblical

1.In a more or less similar vein, Rosemary Radfort Ruether also argued that Paul, the great apostle and missionary to the Gentiles, occupies centre stage in the book of Acts; women appear on this stage only as auxiliary supporters of opponents of influence of Paul's mission. She, however, continues to note: 'However, when we read the occasional Pauline references to women in their own setting, we recognize read the occasional Pauline references to women in their own setting, we recognize
that the Pauline and post-Pauline literature know of women not merely as rich patronesses of the Christian missionary movement but as prominent leaders and missionaries who, in their own right, toiled for the gospel. These women were engaged in missionary and church leadership activity both before Paul and independently of Paul. Without question, they were equal and sometimes even superior to Paul in their work for the gospel' (Ruether 1993:161). discourses about the Jesus whose stories once circulated orally from the mouths of Christian women storytellers.

\section{Biblical discourse at the grassroots: African Christian women's biblical discourse}

As observed earlier in this essay, African cultural contexts are oral in nature. As this article engages orality in the context of religious (read: biblical) discourse and as we have also hinted the role that women played especially as storytellers prior to the canonisation of the text of the New Testament, also acknowledging women's roles as equal participants in the ministry of the gospel of Jesus, it may be worthwhile by way of an introduction to the biblical discourse constructed by grassroots African Christian women, to make some remarks about the African unwritten scriptures.

In their essay titled, 'the Christ for African women' Amoah and Oduyoye (1989) relate an interesting episode of the unwritten scriptures of the Fante people.

\section{Under the wings of the Matriarch Eku? Glimpsing the unwritten sacred texts of the Fante people}

As the Fante people were journeying to what is now their present home, the Matriarch Eku led the way. As they crossed vast tracts of plains without water, they became thirsty. As the leader of her people, Matriarch Eku, did not despair in the midst of an agonising company of followers. Through her encouragement, the people dragged their weary feet along. When they reached a pool of water, they were reluctant to drink for fear of the possibility that the water may have been poisoned. It should be observed that the company should have been constituted by both men and women and children. Matriarch Eku displayed her boldness and willingness to die in the place of her people by being the first one to drink. She and her dog were the first to drink the water and did not die! Then all the people could drink freely and fearlessly.

Amoah and Oduyoye (1989) then conclude:

All human communities have their stories of persons whose individual acts have had lasting effects on the destiny and ethos of the whole group. Such are the people remembered in the stories. (p. 36)

In the preceding story, one that could be depicted as an unwritten sacred text, the saviour figure is a woman. As can be expected, such stories that highlight the significance of female persons in the salvation of their communities will either be subverted or be invisibilised in our patriarchal contexts.

In what follows, we now get a glimpse about how African women in the grassroots, and as can be expected, in nondigital contexts, have the capacity to construct own religious and biblical discourse. 
Amoah and Oduyoye remind us that in order to construct such a discourse, African women will just need a few miracles from the gospels to produce a biblical discourse on Jesus, the worker of wonders. The context in which the women construct their Jesus' embracing biblical hermeneutic is an oral one. Its folktales, folklore and legends are replete with the miracles. The elements therein are hostile, and the forests are full of animals that could become food only if they could be hunted with a minimum of danger (Amoah \& Oduyoye 1989:42).

As they show 'grassroots' African women's understanding of the Christ of the Scriptures, Amoah and Oduyoye present Afua Kuma's hermeneutic.

The biblical discourse on Yesu, from Afua Kuma, one of the esteemed Christian leaders is worth noting:

Yesu, who has received the poor and makes us honourable, our exceedingly wise friend, we depend on you as the tongue depends on the jaw.

\{you are\} the rock. We hide under you, the great bush with cooling shades, the giant tree who enables the climbers to see the heavens.

Yesu, when you walk in the darkness you do not need a lamp. When you step out the sun goes before you and the lightening comes behind you. (Amoah \& Oduyoye 1989:42)

Kuma presents a form of indigenous hermeneutics (cf. Tshehla 2012; West 2012, cf. Dube, Mbuvi \& Mbuwayesango 2012) in the everyday images encountered by 'rural' women in her religious community; the images are brought to bear on her reading of the story of Jesus in the New Testament. Hers is a biblical discourse that not only reveals the (oral) author's relationship with Yesu but it also shows her relationship and that of her community with the rest of creation. May it be designated an ecologically conscious biblical discourse on Yesu?

From the preceding encounter between Kuma and the biblical Yesu, the reader can already conclude that the context is certainly non-digital. If further research were to be performed on the present context of Afua Kuma's ministry, it would not be a surprise that it is still to a large extent finding a solid footing in a rural, oral, non-digital setting: a reality that will be most affirming amongst the socio-economically disenfranchised African Christians, especially in a continent such as Africa, where poverty has historically, even up to today, carried a feminine face.

Although Amoah and Oduyoye celebrate the hermeneutic used by Kuma to unpack her understanding of Yesu, one that interestingly, hardly mentions the cross, the two African women theologians also show how Kuma's biblical discourse basically still follows the trends of African male theologians. On the contrary, they argue for a liberating, women affirming discourse. For them a liberating Christology for African women, whether in digital or non-digital contexts, proclaims:

In Christ all things hold together. The integrity of the woman (a person) as born into a particular culture, and yet belonging to a community of Christ's believers, is ensured. The integrity of the woman (a person) as body/soul is ensured, recognized, and promoted by the way Jesus of Nazareth lived and interacted with women and with persons handicapped by death-dealing cultural demands and by physical and material needs. The Christ has held body/soul together by denouncing oppressive religious practices that ignored well-being. It is this Christ who has become for us, for African women and for Africa, the saviour and liberator of the world. This Christ dominates the spiritual churches of Africa such as the one to which Afua Kuma belongs. The women give expression to a spirituality which enables them to navigate the struggles and problems of humanity. They continue: 'God wears a human face in Africa. God in Christ suffers with women....' (Amoah \& Oduyoye 1989:42)

How may we relate the given discussion on the unwritten scriptures with the written ones, all but emerging from oral cultures? What are we to make of the saviour figures in the two traditions?

\section{Understanding the preceding saviour figures}

Firstly, Matriach Eku's narrative may be celebrated for providing yet another 'unwritten canon', a canon that celebrates the courage of female leaders contrary to the problematic stereotypes in our African patriarchal cultures that women cannot lead. Like the stories that were told by women and men prior to the canonisation of the New Testament text, the Fante 'unwritten scriptures' are, however, received by present-day hearers not only in written form but also in a colonial language. If the revised edition of the book in which they appeared were to be converted into an e-book, they could even be accessed in a digital format. However, it will not be far-fetched to speculate that a hermeneutic by Kuma, and her followers would most probably be cast in the Akan language amongst women who would gladly receive such a message not from a tablet, Facebook and YouTube platforms, television set and online tuition forum, amongst others but from a speaking and performing human being. They are not interested in the written and digitally packaged biblical discourse, but in the oral one. In contrast, especially amongst the many young ones born after technology, the opposite scenario will hold waters.

Secondly, the narratives, like the oral stories that circulated from female mouths in first century Mediterranean CE context, are no longer carrying the authority, which they used to carry. At present, the authority of the written canon of the Bible, one that was basically male-authored, takes the upper hand.

Despite the preceding observations though, also in the context of the present investigation, it is important to note that religious leaders such as Afua Kuma, informed by their own reality, are able to construct their own biblical discourse. Like many believers within the African Independent churches both in South Africa and in the rest of the continent, the modality through which biblical discourse would be discharged is likely, as already hinted, to be non-digital. The 
adherents in such church contexts are not likely to receive sermons and Bible studies from large television screens but from open spaces and church buildings and from the mouths of mostly male interpreters.

As I draw to conclusion, the discourse on the intersection among power, orality, gender and biblical discourse, especially in contexts that have historically not affirmed the ministry of women, I would like to focus on the role (or nonrole) of pastors' wives especially those whose husbands are either founders of large ministries and churches. In line with the theme of the present issue, I am particularly drawn to wives whose spouses are usually featured on television as tele-evangelists.

\section{Power, orality, gender and the digital platform (tele-evangelism): Invisible presence?}

It has been attested by various scholars that Christianity has become a fast-growing religion in sub-Saharan Africa in recent decades. The phenomenal continued growth of charismatic and neo-Pentecostal churches on the African continent is also an indisputable fact. Over and above the preceding observation is the fact that African patriarchy, which existed even prior to colonialism, continues to reign supreme even within the African Christian church.

The existence of patriarchy as it is made manifest in the Christian churches worldwide has also been attested to by various scholars, especially those justice-seeking, womenaffirming biblical scholars and theologians. On the African continent, the works of the Circle of Concerned African women theologians in critiquing patriarchy as it is visible in the works of male theologians and male-identified women theologians, the biblical text, various cultural, political and ecclesiastical landscapes and Empire amongst others are common knowledge (Amoah \& Oduyoye 1989; ed. Dube 2001; Dube \& Kanyoro 2004; Oduyoye 1994; Phiri, Haddad \& Masenya [Ngwan'a Mphahlele] 2003; Ramodibe 1989; Souga 1989; Okure 2000). Within African Christian churches, African culture is used to collude with a specific biblical hermeneutic, also informed by a specific form of deathdealing masculinity, towards the marginalisation of the female voices, especially in ministry.

In the preceding African Christian contexts, women, especially those committed to the Christian Bible, find themselves in what I had previously dubbed, 'freedom in bondage'. Although their understanding of Christ and Christ's mission is that of Deliverer and Redeemer, a problematic understanding of biblical discourse on the status of woman makes them to be invisible and their voice basically muted. Also, although they may form part and parcel of an ecclesiastical tradition that proclaims the equality of women, their lived reality is usually otherwise. For example, earlier on in this essay, I had hinted an opposite women-disaffirming reality experienced by women in the Indian Full Gospel Church of God (cf. Nadar 2005). Catford in
Empowering Pentecostal women also laments the idealrealised gap within the experiences of women in these contexts although the affirmation and equality of women is realised in the baptism and work and gifting provided by the Holy Spirit, the actual lived reality on the ground is far from those truths (cf. the Christian Revival Church [CRC] movement, see also Grey 2011). Rosina Gabaitse, a New Testament scholar writing from the Botswana context, also laments the problematic situation of oppression within Pentecostal settings in which women's wholesale and uncritical embrace of their claimed Godordained position of submission (cf. Eph 5) can be contrasted by the work of the Spirit in Acts 2 (cf. also the prophecy of Jl 2:28-32).

In the context of the wives of powerful men (read: teleevangelists) investigated here, I find the words of Ukah (2016) on target:

[A]lthough Pentecostalism teaches that every believer has equal access to the sacred and sacral goods, in practice, gender roles are skewed against women and in favour of men ... Authority and executive (decision-making) powers within organizations are vested in and exercised by men over women. Women, when they exercise authority, usually do so in areas of/ like the choir or coordinating women's groups and other service sectors. In most African Pentecostal churches, if women are pastors and ritual leaders, they are mainly spouses of church owners who function in practice as Pentecostal first ladies cast in the mould of political first ladies. Pentecostalism challenges patriarchy but reinforces it in other respects. (pp. 377-378, author's own emphasis)

The given observation by Ukah on the wives of church owners who in reality '...function in practice as Pentecostal first ladies cast in the mould of political first ladies' is basically what has led me to ask the following key questions: Whether in an onsite church and/or tent and/or auditorium setting, where are the wives of 'the men of God' (cf. the founders of huge ministries and/or mega-churches)? What is their impact, if any, (especially apart from children, social and women ministries) on the dispatch of biblical discourse, especially in digitalised contact settings?

At first glance, an outside observer may be persuaded to have an impression that the first ladies are integral to and equal partners in the ministries founded by their husbands. Why so? On television, for example, before the slot in which a tele-evangelist would feature as the preacher of the sermon, his wife's face may be shown together with that of her husband. The featuring of the male ministers' faces with those of their wives is also a trend on adverts and posters amongst others. Such marketing tools can also be accessed through Facebook, YouTube and Whatsapp amongst other social media platforms. The preceding trend in my view appears to perpetuate not only the problematic stereotype of an ideal man of God as that of a married heterosexual male person and especially a white male Euro-American person in the context of tele-evangelism (cf. also the question of economic power) but also that of the subordination and invisibility of women in the discharge of biblical discourse as God ordained. 
The words of Ruether (1993) may also be applied to the precarious situation of these first ladies, ones with a seeming contested or rather unsettling 'invisible' presence those who seem to be fully visible only through the presence of their spouses:

Women play the ministerial role by endlessly proving that they can think, feel and act like 'one of the boys'. The 'boys', in turn, accept them only in token numbers that do not threaten their monopoly on ecclesiastical power (anything above five percent is perceived as a threat to this monopoly). But they continually subvert women in practice, intimating that they should retain their 'femininity' by exercising a different ministry from men, as assistant minister in charge of children, youth, and the aged, not as 'the Minister' with full authority. (p. 200). They, women in ministry, therefore find themselves in a double bind, allowed success by being better than men at men's behest while being rebuked to be feminine. (p. 201)

At certain points, depending on the kind of slot, the couple may be featured to engage a specific topic. The bottom line remains as follows though: The ministry is led by the male figure and the discharge of biblical discourse falls squarely in the hands of the male ministers. The preceding norm persists whether on television or onsite. Sometimes contact digitalised settings would depend on the socio-economic muscle of the specific ministry. From my observations, it does not really matter whether the female spouse has ministerial credentials or not, whether her name is usually mentioned together with that of her husband's in the greetings and/or acknowledgements, the person who appears to carry the legitimate authority to deliver and engage in biblical discourse in these ecclesiastical tradition is the male person. In this space then, it appears that there is a clear intersection between (male) power and gender, orality and biblical discourse. It would be curious though to see the reversed situation in which the founder of the ministry is a married woman, especially within African ecclesiastical settings.

\section{Conclusion}

On the one hand, orality, especially before its interruption by literacy (cf. the first century Mediterranean era) and technological advances in the digital era, seems to have been a modality in which all human beings, including those whose power is not legitimated by patriarchy are affirmed. Women, especially African Christian women, although not always affirmed within mainstream, malestream biblical discourse (be this through the medium of television or not), have a way in which they can construct their own women-affirming biblical discourse, especially orally, in non-digital or partially digitalised contexts. Women founders of ministries such as Afua Kuma and Mme Nku amongst others, especially in African independent churches whose membership may have basically little or no access to digital platforms, can hold their own in a men's world. They do not seem to need the legitimation of men as partners in ministries.

On the other hand, the digital media space, in particular the television platform, is replete with examples of tele-evangelists across races who grace our screens and preach the word. As it has hopefully become evident from the preceding discussion, what appears to be common, and equally disconcerting, is that the only thing that has changed is the medium of the sermon delivery, patriarchy remains entrenched. What in the past used to take place in the form of physical delivery of sermons to a congregation or an audience in church settings has now, depending on the financial muscle of the preacher, been replaced and supplemented by digital delivery through television channels, amongst others. The preachers, though, remain male. Like many, a Pentecostal woman in heterosexual marriage settings, a wife of a man of God (read: tele-evangelist) features as this invisible Other, in whom the oneness that is to be end result of a heterosexual marriage union (cf. Gn 2:24), seems to be made manifest in the one ministry in which biblical discourse gets discharged by one powerful male person, that is, her husband.

\section{Acknowledgements Competing interests}

The author declares that she has no financial or personal relationships that may have inappropriately influenced her in writing this article.

\section{Author's contributions}

M.M. is the sole author of this article.

\section{Ethical considerations}

This article followed all ethical standards for research without direct contact with human or animal subjects.

\section{Funding information}

This research received no specific grant from any funding agency in the public, commercial or not-for-profit sectors.

\section{Data availability}

Data sharing is not applicable to this article as no new data were created or analysed in this study.

\section{Disclaimer}

The views and opinions expressed in this article are those of the author and do not necessarily reflect the official policy or position of any affiliated agency of the author.

\section{References}

Amoah, A. \& Oduyoye, M.A., 1989, 'The Christ for African women', in V. Fabella \& M.A. Oduyoye (eds.), With passion and compassion: Third world women doing theology, pp. 35-46, Orbis, Maryknoll, NY.

Bowler, K., 2019, The perilous power of the preacher's wife, The New York Times, viewed 28 September 2021, from https://www.nytimes.com/2019/10/12/ opinion/sunday/evangelical-preachers-pastors.html.

Carroll, R.P., 2006, Jeremiah, volume 1, Sheffield Phoenix, Sheffield.

Culley, R.C., 1963, 'An approach to the problem of the oral tradition', Vetus Testamentum, 13(2), 113-125. https://doi.org/10.2307/1516484

Dewey, J., 1998, 'From oral stories to written text', in P. Kwok \& E. Schüssler Fiorenza (eds.), Women's sacred scriptures, concilium 3, pp. 20-28, SCM, London. 
Dube, M.W., Andrew, M.M. \& Mbuwayesango, D.R. (eds.), 2012, Postcolonial perspective in African biblical interpretations, SBL, Atlanta, GA.

Dube, M.W. (ed.), 2001, Other ways of reading: African women and the bible, SBL, Atlanta, GA.

Dube, M.W. \& Kanyoro, R.A., (eds.), 2004, Grant me justice: HIV/AIDS \& gender readings of the bible, Cluster Publications, Pietermaritzburg.

Grey, J., 2011, Three's a crowd: Pentecostalism, hermeneutics, and the Old Testament Pickwick Publications, Eugene, OR.

Nadar, S., 2005, 'On being the Pentecostal church: Pentecostal women's voices and visions', in I.A. Phiri \& S. Nadar (eds.), On being church: Women's voices and visions, pp. 60-79, WCC, Geneva.

Niditch, S., 1996, Oral world and written word: Ancient Israelite literature, Westminster John Knox Press, Louisville, KY.

Oduyoye, M.A., 1994, Daughters of Anowa, African women and patriarchy, Orbis, Maryknoll, NY.

Okure, T., 2000, 'First was the life, not the book', in T. Okure (ed.), To cast fire upon the earth: Bible and mission collaborating in today's multicultural global context, pp. 194-227, Cluster, Pietermaritzburg.

Phiri, I.A., Haddad, B. \& Madipoane M. (ngwan'a Mphahlele) (eds.), 2003, HIV/AIDS, African women and faith communities, Cluster, Pietermaritzburg.
Ramodibe, D., 1989, 'Women and men building together the church in South Africa', in V. Fabella \& M.A. Oduyoye (eds.), With passion an compassion: Third world women doing theology, pp. 14-21, Orbis, Maryknoll, NY.

Ruether, R.R., 1993, Sexism and god-talk: Toward a feminist theology, Beacon, Boston MA.

Schüssler Fiorenza, E, 1994, In memory of her: A feminist theological reconstruction of Christian origins, Crossroad, New York, NY

Souga, T., 1989, 'The Christ event from the viewpoint of African women: A catholic perspective', in V. Fabella \& M.A. Oduyoye (eds.), With passion an compassion: Third world women doing theology, pp. 22-29, Orbis, Maryknoll, NY.

Tshehla, S., 2012, 'Uncelebrated readers of the Bible: The illustrative sase of early Basotho Christians', in M.W. Dube, A. Mbuvi \& D. Mbuwayesango (eds.), Postcolonial biblical interpretations, pp. 97-112, SBL, Atlanta.

Ukah, A., 2016, 'The deregulation of piety in the context of neoliberal globalization: African Pentecostalisms in the twenty-first century', in V. Synan, A. Yong \& J. Kwabena Asamoah-Gyadu (eds.), Global renewal christianity: Spiritempowered mov pp. 362-379, Charisma House, Lakemary, FL.

West, G.O., 2012, 'Indigenous biblical hermeneutics: Voicing continuity and distinctiveness', in M.W. Dube, A.M. Mbuvi \& D.R. Mbuwayesango (eds.), Postcolonial biblical interpretations, pp. 85-96, SBL, Atlanta. 